\title{
Effect of decreasing dietary phosphorus supply on net recycling of inorganic phosphate in lactating dairy cows
}

\author{
L. Puggaard, N. B. Kristensen, ${ }^{1}$ and J. Sehested \\ Department of Animal Health and Bioscience, Faculty of Agricultural Sciences, Aarhus University, DK-8830 Tjele, Denmark
}

\begin{abstract}
Five ruminally cannulated lactating Holstein cows, fitted with permanent indwelling catheters in the mesenteric vein, hepatic vein, portal vein, and an artery were used to study intestinal absorption and net recycling of inorganic phosphate $\left(\mathrm{P}_{\mathrm{i}}\right)$ to the gastrointestinal tract. Treatments were low $\mathrm{P}$ (LP; $2.4 \mathrm{~g}$ of $\mathrm{P} /$ $\mathrm{kg}$ of $\mathrm{DM}$ ) and high $\mathrm{P}(\mathrm{HP} ; 3.4 \mathrm{~g}$ of $\mathrm{P} / \mathrm{kg}$ of $\mathrm{DM})$. The dietary total $\mathrm{P}(\mathrm{tP})$ concentrations were obtained by replacing $0.50 \%$ calcium carbonate in the LP diet with $0.50 \%$ monocalcium phosphate in the HP diet. Diets were fed for $14 \mathrm{~d}$ and cows were sampled on $\mathrm{d}$ 14 in each period. Cows were fed restrictively, resulting in equal dry matter intakes as well as milk, fat, and protein yields between treatments. Net $\mathrm{P}_{\mathrm{i}}$ recycling (primarily salivary) was estimated as the difference between net portal plasma flux (net absorption of $\mathrm{P}_{\mathrm{i}}$ ) and apparently digested tP (feed - fecal tP difference). Phosphorus intake, apparently digested tP, and fecal tP excretion decreased with LP. An effect of decreased tP intake on net portal plasma flux of $\mathrm{P}_{\mathrm{i}}$ could not be detected. However, despite numerically minute net fluxes across the liver, the net splanchnic flux of $\mathrm{P}_{\mathrm{i}}$ was less in LP compared with that in HP. Though arterial plasma $P_{i}$ concentration decreased, net $P_{i}$ recycling was not decreased when tP intake was decreased, and recycling of $\mathrm{P}_{\mathrm{i}}$ was maintained at the expense of deposition of $\mathrm{P}_{\mathrm{i}}$ in bones. Data are not consistent with salivary $\mathrm{P}_{\mathrm{i}}$ secretion being the primary regulator of $\mathrm{P}_{\mathrm{i}}$ homeostasis at low tP intakes. On the contrary, maintaining salivary $\mathrm{P}_{\mathrm{i}}$ recycling at low $\mathrm{tP}$ intakes indicates that rumen function was prioritized at the expense of bone $\mathrm{P}$ reserves.

Key words: dairy cow, phosphorus, absorption, recycling
\end{abstract}

\section{INTRODUCTION}

Phosphorus plays an important role in the production and health of cattle and is essential for rumen

Received July 1, 2010.

Accepted November 26, 2010.

${ }^{1}$ Corresponding author: nbk@agrsci.dk microbial fermentation. Rates of ruminal fermentation and protein synthesis are impaired if the dietary total $\mathrm{P}$ (tP) supply is insufficient, and digestibility of $\mathrm{OM}$ may be decreased (Müschen et al., 1988; Kincaid and Rodehutscord, 2005). Dietary tP and salivary secretion of inorganic phosphate $\left(\mathbf{P}_{\mathbf{i}}\right)$ are the major sources of $\mathrm{P}_{\mathrm{i}}$ input to the rumen (Kincaid and Rodehutscord, 2005) and a significant part of $\mathrm{P}_{\mathrm{i}}$ secreted via saliva is reabsorbed in the digestive tract, thereby creating a system of $\mathrm{P}_{\mathrm{i}}$ recycling.

Valk et al. (2002) demonstrated that lowering plasma $\mathrm{P}_{\mathrm{i}}$ concentration, through a decrease in dietary tP intake, induced a decrease in salivary $\mathrm{P}_{\mathrm{i}}$ concentration. Inorganic phosphate supply to the rumen is, therefore, assumed to be affected by changes in the dietary tP concentration by 1) the direct effect of dietary tP concentration and 2) indirectly through the effect of dietary tP concentration on $\mathrm{P}_{\mathrm{i}}$ concentration in plasma and saliva (Kincaid and Rodehutscord, 2005). Reynolds et al. (1991) observed that net portal-drained visceral (PDV) absorption of $\mathrm{P}_{\mathrm{i}}$ exceeded total $\mathrm{P}$ intake, indicating a $\mathrm{P}_{\mathrm{i}}$ recycling via saliva and other digestive secretions. Breves and Schröder (1991) suggested that the daily endogenous secretion of $\mathrm{P}_{\mathrm{i}}$ accounts for 30 to $60 \mathrm{~g}$ of $\mathrm{P}$ in dairy cows. Thus, recycling of $\mathrm{P}_{\mathrm{i}}$ is responsible for a substantial part of ruminal microbial $\mathrm{P}$ supply. Nonetheless, there is a shortage of quantitative data of salivary secretion of $\mathrm{P}_{\mathrm{i}}$ and sparse information on regulation and extent of $\mathrm{P}_{\mathrm{i}}$ recycling in lactating dairy cattle.

Inorganic phosphate recycling may generate an endogenous fecal $\mathrm{P}$ loss through incomplete reabsorption of salivary $P_{i}$ because fecal excretion is the most quantitatively important excretion route in cattle (Scott et al., 1985; Bravo et al., 2003). Therefore, the utilization of $\mathrm{P}$ by dairy cows is $31 \%$ on a production cycle basis (Poulsen, 2009). Total P excretion has been shown to increase in response to increasing dietary tP supply (Scott et al., 1985; Bravo et al., 2003), and a decrease in tP intake is, therefore, expected to decrease fecal tP excretion and increase $\mathrm{P}$ utilization by cattle (Wu et al. 2001; Knowlton and Herbein, 2002). The objective of the present study was to quantify the net recycling of $\mathrm{P}_{\mathrm{i}}$ to the gastrointestinal tract and the bone tissue 
Table 1. Ingredient and nutrient composition of experimental diets ( $\mathrm{g} / \mathrm{kg}$ of DM if not otherwise noted)

\begin{tabular}{lcc}
\hline & \multicolumn{2}{c}{ Treatment $^{1}$} \\
\cline { 2 - 3 } Item & LP & HP \\
\hline Ingredient $^{2}$ & 500 & 500 \\
Corn silage $^{2}$ & 200 & 200 \\
Grass clover silage & 105 & 105 \\
Sugar beet molasses & 63.9 & 63.9 \\
Sugar beet pulp & 100 & 100 \\
Soybean meal & 10 & 10 \\
Mineral premix ${ }^{4}$ & 2.5 & 2.5 \\
Urea & 10 & 10 \\
Vegetable fat & 5 & \\
Calcium carbonate & & 5 \\
Monocalcium phosphate & 2.6 & 2.6 \\
MetaSmart & 1 & 1 \\
Chromium(III)oxide & & \\
Nutrient & 44.2 & 43.2 \\
DM, \% & 892 & 899 \\
OM & 302 & 295 \\
NDF & 140 & 148 \\
CP & 34.7 & 34.7 \\
Crude fat & 7.2 & 6.9 \\
Ca & 2.4 & 3.4 \\
P & 6.76 & 6.76 \\
NE ${ }_{\mathrm{L}}{ }^{6}{ }^{\mathrm{M}} \mathrm{MJ} / \mathrm{kg}$ of DM & & \\
\hline
\end{tabular}

${ }^{1}$ Experimental diets had the same composition of ingredients with the exception that the LP (low-phosphorus) diet contained $0.5 \%$ of DM calcium carbonate, which was substituted by $0.5 \%$ of DM monocalcium phosphate in the HP (high-phosphorus) diet.

${ }^{2}$ Chemical composition of corn silage: DM, 363 (g/kg); ash, 31; CP, 87; NDF, 375; starch, 320; in vitro OM digestibility, $72.5 \%$.

${ }^{3}$ Chemical composition of grass clover silage: DM, 407 (g/kg); ash, 86; CP, 146; NDF, 363; in vitro OM digestibility, $78.8 \%$.

${ }^{4}$ VM 1 (Vitfoss, Gråsten, Denmark) contained (per kg): Ca, $180 \mathrm{~g}$; P, $4 \mathrm{~g} ; \mathrm{Mg}, 65 \mathrm{~g}$; Na, $80 \mathrm{~g}$; S $30 \mathrm{~g}$; vitamin A, $693 \mathrm{kIU}$; vitamin D, 146 kIU; $\alpha$-tocopherol, 4,620 mg; Mn, 3,080 mg; Cu, $693 \mathrm{mg}$; Co, $19 \mathrm{mg}$; Zn, 3,460 mg; I, $173 \mathrm{mg}$; Se, $38.5 \mathrm{mg}$.

${ }^{5}$ 2-Hydroxy-4-(methylthio)-butanoic acid isopropyl ester (MetaSmart, Adisseo, Antony, France).

${ }^{6}$ Calculated at DMI level of $20 \mathrm{~kg} / \mathrm{d}$ according to Norfor feed evaluation system (www.norfor.info).

balance of tP in lactating cows challenged with a low dietary tP concentration. By comparing a low tP with a high $\mathrm{tP}$ ration, we aimed at testing if decreased tP intake would be a double challenge to rumen function (decreased $\mathrm{P}$ input from both feed and saliva) or if compensatory mechanisms would affect the relationship between $\mathrm{tP}$ intake and $\mathrm{P}_{\mathrm{i}}$ recycling. We hypothesized that recycling of $P_{i}$ would be decreased with decreased dietary tP because of a decreased intestinal absorption and subsequent decreased plasma concentration of $\mathrm{P}_{\mathrm{i}}$.

\section{MATERIALS AND METHODS}

The present experiment complied with the Danish Ministry of Justice Law no. 382 (June 10, 1987), Act no. 726 (September 9, 1993), concerning experiments with animals and care of experimental animals.

\section{Animals, Design, Feeding, and Samplings}

Five ruminally cannulated (\#1C; Bar Diamond Inc., Parma, ID) Danish Holstein cows, second parity, 597 $\pm 31 \mathrm{~kg}$ of BW, and $145 \pm 55$ DIM were used in an experiment with 2 treatments and 2 periods, and 2 or 3 cows on each treatment in each period. Cows were fitted with permanent indwelling catheters in the mesenteric vein, hepatic vein, hepatic portal vein, and an artery at least 6 wk before expected calving. Surgery was performed according to Kristensen et al. (2007). Cows were randomly assigned to one of the 2 treatment sequences. Treatments were low $\mathrm{P}$ (LP, dietary tP concentration of $2.4 \mathrm{~g} / \mathrm{kg}$ of $\mathrm{DM})$ or high $\mathrm{P}(\mathbf{H P}$, dietary tP concentration of $3.4 \mathrm{~g} / \mathrm{kg}$ of DM). The HP diet meets the recommendations by NRC (2001) as well as current Danish recommendations (Sehested, 2004). The TMR were based on the same grain and forage ingredients (Table 1). The different dietary tP concentrations were obtained by replacing $0.50 \%$ calcium-carbonate in the LP diet with $0.50 \%$ mono-calcium-phosphate in the HP diet. Chromium(III)oxide $\left(\mathrm{Cr}_{2} \mathrm{O}_{3}\right)$ was used as a flow-marker to determine fecal output and total tract digestibility of tP and NDF. To decrease day-to-day variation in rations and to avoid drift in silage composition, the TMR were prepared once, then vacuum packed in portions of 10 to $15 \mathrm{~kg}$ (Webomatic I22; Webo A/S, Aarup, Denmark) and stored below $-20^{\circ} \mathrm{C}$ until the day before feeding. Rations stored in vacuum packs were thawed overnight. Cows were fed $20 \mathrm{~kg}$ of $\mathrm{DM} / \mathrm{d}$ in 3 equal-sized portions at 0800,1600 , and 2400 $\mathrm{h}$, which allowed for an 8-h sampling window. Orts were removed and registered daily at $0730 \mathrm{~h}$. Cows were kept in tie stalls with wood shavings as bedding and were milked at 0530 and $1530 \mathrm{~h}$.

The diets were fed for $14 \mathrm{~d}$ and cows were sampled at d 14 in each period. Blood plasma flows in the splanchnic tissues were determined by downstream dilution of $p$-aminohippuric acid (pAH; $175 \mathrm{mmol} / \mathrm{L})$ continuously infused $(28 \pm 2 \mathrm{mmol} / \mathrm{h})$ into the mesenteric vein. The infusates were prepared by dissolving $\mathrm{pAH}$ in sterile water and $\mathrm{pH}$ was adjusted to 7.4. Infusates were filtered (Vacu Cap 0.8/0.2 $\mu \mathrm{m}$; Pall Corp., Ann Arbor, MI) and autoclaved. Infusion was initiated $1 \mathrm{~h}$ before the first sampling. Sampling of arterial, portal, and hepatic blood was initiated 30 min before morning feeding and conducted simultaneously every hour for 8 h. From each catheter, $1 \mathrm{~mL}$ of heparinized whole blood was collected in a 1-mL syringe for immediate blood gas analysis and determination of arterial $\mathrm{pH}(\mathrm{ABL}$ 520; Radiometer A/S, Copenhagen, Denmark). Then a total of $30 \mathrm{~mL}$ of blood was collected and the blood was immediately stabilized in Na-heparin tubes (Greiner BioOne GmbH, Kremsmuenster, Austria). Blood sam- 
ples were placed on ice, and plasma was harvested after centrifugation at $3,000 \times g$ for $20 \mathrm{~min}$ at $4^{\circ} \mathrm{C}$. Ruminal fluid was collected every hour by sampling from the ventral ruminal sac using an extended suction strainer (\#RT; Bar Diamond) and a 50-mL syringe.

Ruminal fluid $\mathrm{pH}$ was measured immediately after sampling using a combination electrode (PHC2002-8; Hach Lange APS, Brønshøj, Denmark) and a pH meter calibrated at pH 4.005 and 7.000 (PHM 240; Hach Lange APS). Immediately after $\mathrm{pH}$ measurement, 2 subsamples of ruminal fluid were stored at $-20^{\circ} \mathrm{C}$ : a sample stabilized with 5\% meta-phosphoric acid (MPA; for VFA and ammonia analysis) and an unstabilized sample. Spot samples of urine were collected every hour by hand-stimulation. Feces were collected as grab samples morning (0630 to $0800 \mathrm{~h}$ ) and afternoon (1400 to $1500 \mathrm{~h}$ ) on the day before sampling, and on the day of sampling. Milk yield and feed intake were recorded daily. Milk samples were collected morning and afternoon the day before sampling and on the day of sampling. All samples except milk samples were stored at $-20^{\circ} \mathrm{C}$ until further analysis.

\section{Analytical Procedures}

The hematocrit was determined on all arterial samples by centrifugation of heparin-stabilized arterial plasma at $13,000 \times g$ for $6 \mathrm{~min}$ at ambient temperature. The concentration of inorganic phosphate was determined in heparinized plasma and ruminal fluid using an ammonium molybdate-based kit (ABX Pentra Phosphorus CP kit; Horiba ABX, Montpellier, France) adapted to run on a Cobas Mira Plus autoanalyzer (Triolab A/S, Brøndby, Denmark). The method was calibrated according to standards with the concentrations $0.25,2.5$, and $5 \mathrm{mM}$ phosphate obtained by dissolving disodium hydrogen phosphate in deionized water. Randox Bovine Assayed Sera level 1, 2, and 3 were used as controls (Randox Laboratories Ltd., Crumlin, UK). Before analysis untreated ruminal fluid was centrifuged at $3,000 \times$ $g$ for $15 \mathrm{~min}$ at $4^{\circ} \mathrm{C}$ followed by centrifugation at 20,000 $\times g$ for 15 min at $4^{\circ} \mathrm{C}$. The supernatant was diluted 1:2 with deionized water.

For tP determination, milk, feces, and feed samples were destroyed by a dry ash method $\left(450^{\circ} \mathrm{C}\right.$ for $\left.3 \mathrm{~h}\right)$ and urine by a wet ash method (using perchloric and nitric acids). Phosphorus content was determined by the ammonium vanadate method as described by Stuffins (1967).

Concentrations of pAH in plasma and urine were determined according to the method described by Harvey and Brothers (1962) using a continuous-flow analyzer (Autoanalyzer 3, method US-216-72 Rev.1; Seal Ana- lytical Ltd, Burgess Hill, UK), following a deacetylation step (Kristensen et al., 2009).

Ruminal concentrations of VFA were determined by gas chromatography according to Kristensen et al. (1996). For ammonia analysis, MPA-stabilized rumen fluid samples were diluted 1:20 in phosphate buffer $(\mathrm{pH}$ 7.8). Ammonia was determined using a glutamate dehydrogenase based kit (AM 1015; Randox laboratories, Ltd.) and Randox Ammonia Ethanol level 1, 2, and 3 as controls.

Feed DM was determined by drying samples at $60^{\circ} \mathrm{C}$ for $48 \mathrm{~h}$ in a forced-air oven. Crude ash was determined after combustion at $525^{\circ} \mathrm{C}$ for $6 \mathrm{~h}$. Organic matter was determined as the difference between DM and crude ash. Neutral detergent fiber was determined as amylasetreated NDF using the fibertec system as described by Mertens (2002). Nitrogen content in feces was determined according to the Dumas method described by Hansen (1989). Crude fat was determined as petroleum ether extract in an acid hydrolysate according to Stoldt (1952). Content of $\mathrm{Cr}_{2} \mathrm{O}_{3}$ in feed and feces was determined by spectrophotometric determination according to Schurch et al. (1950).

\section{Calculations and Statistical Procedures}

Production of ECM was calculated according to the formula described by Sjaunja et al. (1991). Fecal tP output was calculated as (dietary $\mathrm{Cr}_{2} \mathrm{O}_{3}$ concentration $\times$ DMI/fecal $\mathrm{Cr}_{2} \mathrm{O}_{3}$ concentration) $\times$ fecal tP concentration. Phosphorus excretion in urine was calculated by multiplying daily diuresis (infusion rate of pAH/urinary pAH concentration) by tP content in urine. Apparently digested $\mathrm{tP}$ was calculated as the difference between tP intake and tP excretion in feces. Balance of tP was calculated as the difference between tP input in feed and tP output in feces, urine, and milk. Calculations of portal and hepatic blood plasma flows, net portal fluxes, net hepatic fluxes, and net splanchnic fluxes of phosphate were done as described by Kristensen et al. (2007). The $\mathrm{P}_{\mathrm{i}}$ absorbed to the portal blood in excess of apparently digested $\mathrm{tP}$ has been transferred to the gut from an endogenous source (i.e., recycled). Accordingly, $\mathrm{P}_{\mathrm{i}}$ recycling was calculated as net portal plasma flux of $\mathrm{P}_{\mathrm{i}}$ - apparently digested tP. Data on fluxes and balance are given in $\mathrm{g} / \mathrm{d}$ using the atomic weight of $\mathrm{P}(30.97 \mathrm{~g} /$ mol).

Data were analyzed by ANOVA using the MIXED procedure in SAS (Statistical Analysis System version 9.2 SAS Institute Inc., Cary, NC). Data on DMI, milk production, $\mathrm{tP}$ intake, and $\mathrm{tP}$ excretion in feces, urine, and milk, as well as apparently digested tP, tP balance, and $\mathrm{P}_{\mathrm{i}}$ recycling, were analyzed using a model including the fixed effects of treatment, sequence, and 
Table 2. Dry matter intake, NDF digestibility, and milk production parameters

\begin{tabular}{lcccc}
\hline & \multicolumn{2}{c}{ Treatment $^{1}$} & & \\
\cline { 2 - 3 } Item & LP & HP & $(\mathrm{SEM}$ & \\
\hline DMI, kg/d & 19.8 & 19.6 & 0.37 & $P$-value \\
\hline $\begin{array}{l}\text { Digestibility of NDF, \% } \\
\text { Yield, kg/d }\end{array}$ & 47.8 & 52.6 & 1.77 & 0.67 \\
Milk & & & & \\
ECM $^{3}$ & 30.6 & 30.8 & 2.69 & 0.71 \\
Fat & 29.7 & 29.2 & 1.84 & 0.80 \\
Protein & 1.20 & 1.22 & 0.072 & 0.66 \\
& 0.87 & 0.88 & 0.079 & 0.88 \\
\hline
\end{tabular}

${ }^{1}$ Experimental diets had the same composition of ingredients with the exception that LP (low phosphorus) contained $0.5 \%$ of DM calcium carbonate and HP (high phosphorus) contained $0.5 \%$ of DM monosodium phosphate.

${ }^{2} P$-value for treatment effect.

${ }^{3}$ Calculated according to Sjaunja et al. (1991).

period, and the random effect of cow within sequence. Data on ruminal fluid, arterial variables, blood flow, and flux measurements were evaluated as repeated measurements using the auto regressive 1 covariance structure. The model included the fixed effects of treatment, sequence, period, sample, and the interaction treatment by sample. The effect of cow within sequence was included as a random effect. Data are presented as least squares means \pm residual standard error of means. Significance was declared at $P \leq 0.05$ and tendencies were considered at $0.05<P \leq 0.10$.

\section{RESULTS}

\section{Dry Matter Intake, Digestibility of NDF, and Milk Production}

The total amount of DM offered was limited to 20 $\mathrm{kg} / \mathrm{d}$ for both treatments, and the actual DMI was unaffected by treatment $(P=0.67$; Table 2$)$. Digestibility of NDF was less in LP $(P=0.02 ; 47.8 \pm 1.8)$ compared with HP (52.6 \pm 1.8$)$, whereas milk, fat, protein, and ECM yields were unaffected by treatment $(P=0.66$ to $P=0.88)$.

\section{Digestibility and tP Balance}

As planned, tP intake was less in LP $(P=0.001)$ compared with HP, whereas $\mathrm{Ca}$ intake was similar among diets (LP, $142 \pm 3$; HP, $134 \pm 3 \mathrm{~g} / \mathrm{d}$ ). The tP excretion in feces was decreased with LP $(P=0.02$; Table 3$)$, but digestibility of $\mathrm{tP}$ was not affected by treatment $(P=$ 0.82 ). Nevertheless, apparently digested tP, calculated as difference between tP intake and tP in feces, was less in LP $(P=0.01 ; 26.3 \pm 2.1 \mathrm{~g} / \mathrm{d})$ compared with HP $(36.4 \pm 2.1 \mathrm{~g} / \mathrm{d})$. The urinary tP excretion was lower in cows fed $\mathrm{LP}(P=0.05)$ but the magnitude of the change was small. The tP excretion in milk tended to decrease $(P=0.10)$ in LP compared with HP. The tP concentration in milk was $0.82 \pm 0.02 \mathrm{~g} / \mathrm{kg}$ and 0.84 $\pm 0.02 \mathrm{~g} / \mathrm{kg}$ with LP and HP, respectively (data not shown). The tP balance, calculated as the difference between tP intake and tP excreted in feces, urine, and milk was less in LP $(1.0 \pm 2.1 \mathrm{~g} / \mathrm{d})$ compared with that in $\mathrm{HP}(P=0.02 ; 10.4 \pm 2.1 \mathrm{~g} / \mathrm{d})$. Apparently digested Ca was not affected $(P=0.13)$ by treatment $(\mathrm{LP}, 36 \pm$ 5 ; HP, $48 \pm 5 \mathrm{~g} / \mathrm{d})$.

\section{Urinary, Ruminal, and Arterial Variables}

No effects of treatment or time on urine $\mathrm{pH}(P=$ 0.24 to $P=0.57$; Table 4 ) were observed. Ruminal $\mathrm{pH}$ was unaffected by treatment $(P=0.20)$ and no treatment by time interaction was detected $(P=0.65)$. The $\mathrm{P}_{\mathrm{i}}$ concentration in ruminal fluid was decreased with LP $(P=0.0001)$, and no interaction between treatment and time was detected $(P=0.34$; Figure 1). The ruminal ammonia concentration, total ruminal VFA concentration, and molar percentage of VFA were not affected by treatment $(P=0.12$ to $P=0.98)$. The molar proportions of propionate, isovalerate, valerate, and caproate increased after feeding $(P<0.01)$, the molar proportion of acetate decreased after feeding $(P$ $=0.02$ ) , and the molar proportion of isobutyrate was decreased only at the sampling 30 min after feeding $(P$ $<0.01)$.

Arterial whole blood $\mathrm{pH}$ was greater in LP compared with that in HP $(P=0.04$; Table 5$)$, but was not affected by sampling time $(P=0.16)$.

No overall major differences in patterns for arterial hematocrit and oxygen concentration were noted. A

Table 3. Digestibility of total phosphorus (tP), excretion of $t P$, and tP balances

\begin{tabular}{lcccc}
\hline & \multicolumn{2}{c}{ Treatment $^{1}$} & & \\
\cline { 2 - 3 } Item & LP & HP & & SEM \\
$(\mathrm{n}=5)$ & $P$-value \\
\hline Digestibility of tP, $\%$ & 54.9 & 54.0 & 2.64 & 0.82 \\
P, g of P/d & & & & \\
P intake & 47.9 & 67.2 & 1.18 & 0.001 \\
tP in feces & 21.6 & 30.8 & 1.73 & 0.02 \\
tP in urine & 0.22 & 0.26 & 0.015 & 0.05 \\
tP in milk & 25.1 & 25.8 & 2.10 & 0.10 \\
Apparently digested $\mathrm{tP}^{3}$ & 26.3 & 36.4 & 2.08 & 0.01 \\
tP balance & 0.95 & 10.4 & 2.06 & 0.02 \\
\hline
\end{tabular}

${ }^{1}$ Experimental diets had the same composition of ingredients with the exception that LP (low phosphorus) contained $0.5 \%$ of DM calcium carbonate and HP (high phosphorus) contained $0.5 \%$ of DM monosodium phosphate.

${ }^{2} P$-value of treatment effect.

${ }^{3}$ Apparently digested $\mathrm{P}$ denotes the feed - fecal difference.

${ }^{4}$ Balance was calculated as the difference between $\mathrm{P}$ input via feed and $\mathrm{P}$ output via feces, urine, and milk. 


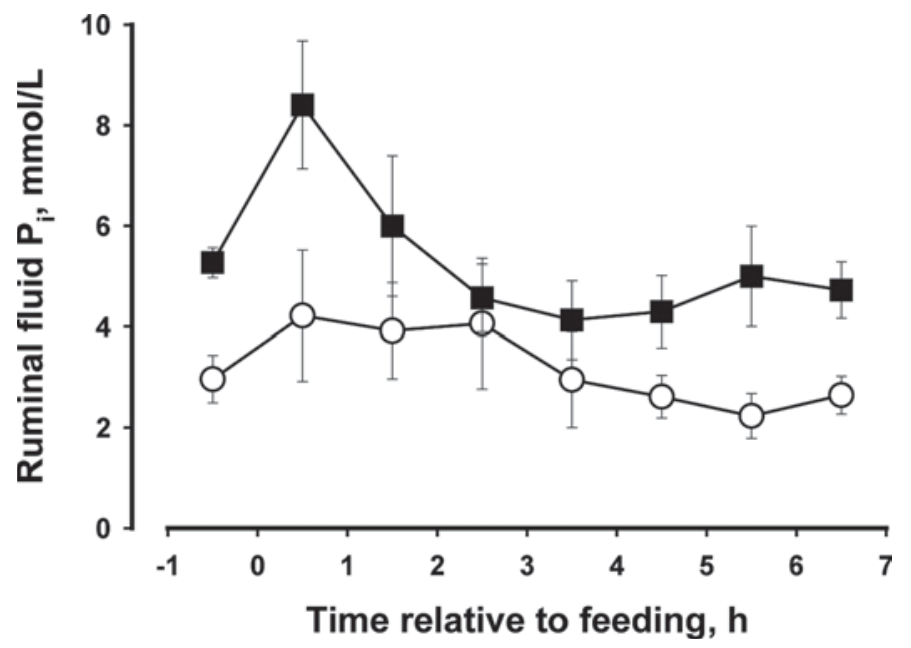

Figure 1. Concentration of inorganic phosphate $\left(\mathrm{P}_{\mathrm{i}}\right)$ in ventral ruminal fluid in cows fed either a low-phosphorus $(\mathrm{P})$ ration $(2.4 \mathrm{~g}$ of $\mathrm{P} / \mathrm{kg}$ of DM; $\mathrm{O}$ ) or a high-P ration (3.4 $\mathrm{g}$ of $\mathrm{P} / \mathrm{kg}$ of DM; $)$. Samples were collected $0.5 \mathrm{~h}$ before morning feeding as well as $0.5,1.5,2.5,3.5$, $4.5,5.5$, and $6.5 \mathrm{~h}$ after morning feeding. Each data point is the mean of 5 observations \pm standard error. The $\mathrm{P}_{\mathrm{i}}$ concentration in ruminal fluid was affected by treatment $(P=0.0001)$ as well as sampling time $(P=0.006)$, but no interaction was detected $(P=0.34)$.

transient increase in hematocrit and oxygen with LP 30 min after feeding caused an interaction between sampling time and treatment $(P=0.07$ and $P=0.02$, respectively). In line with the greater blood $\mathrm{pH}$ in $\mathrm{LP}$, the arterial carbon dioxide concentration tended to increase in LP $(P=0.07)$. Arterial plasma $P_{i}$ was less with LP $(P=0.001 ; 1.15 \pm 0.10 \mathrm{mmol} / \mathrm{L})$ compared with HP $(1.85 \pm 0.10 \mathrm{mmol} / \mathrm{L})$ and with both treatments, plasma $P_{i}$ was observed to increase in samples obtained 30 min after feeding $(P=0.01$; Figure 2$)$.

\section{Blood Flows, Net Fluxes, and Recycling of $P_{i}$}

Portal, hepatic, and hepatic arterial blood plasma flows were not affected by treatment $(P=0.46$ to $P=$ 0.70 ; Table 6$)$. Portal blood plasma flow tended to be affected by sampling time $(P=0.10)$ without showing any meaningful pattern. Hepatic vein and hepatic arterial blood plasma flows were unaffected by sampling time $(P=0.39$ to $P=0.78)$. Treatment and sampling time was without effect for net portal plasma flux of $\mathrm{P}_{\mathrm{i}}$ (net absorption of $\mathrm{P}_{\mathrm{i}} ; P=0.20$ to $P=0.33$ ). The net hepatic plasma flux of $\mathrm{P}_{\mathrm{i}}$ was not affected by treatment or sampling time $(P=0.13$ to $P=0.74)$. However, the net splanchnic plasma flux of $\mathrm{P}_{\mathrm{i}}$ increased $(P=0.05)$ in $\mathrm{HP}(68.6 \pm 5.4 \mathrm{~g} / \mathrm{d})$ compared with that in LP $(56.4$ $\pm 5.4 \mathrm{~g} / \mathrm{d}$ ), whereas sampling time was without effect on net splanchnic plasma flux of $\mathrm{P}_{\mathrm{i}}(P=0.37)$. Net recycling of $\mathrm{P}_{\mathrm{i}}$ was not affected by treatment $(P=0.86)$ and averaged $29.7 \pm 4.2$ and $28.6 \pm 4.2$ with $\mathrm{LP}$ and HP, respectively.

\section{DISCUSSION}

\section{DMI and Milk Production}

The DMI was maintained equal among treatments in the present study by restricting feed allowance to $20 \mathrm{~kg}$ of DMI/d and with equal intakes, milk, fat, and protein production were unaffected by decreased tP intake. A decrease in DMI, milk yield, and loss of BW are among the initial signs of $\mathrm{P}$ deficiency (Call et al., 1987). The present study was not designed to show effects of decreased $\mathrm{P}$ intake on production variables. In a study on lactating goats, Müschen et al. (1988) observed a

Table 4. Urinary and ruminal variables

\begin{tabular}{|c|c|c|c|c|c|c|}
\hline \multirow[b]{2}{*}{ Item } & \multicolumn{2}{|c|}{ Treatment $^{1}$} & \multirow{2}{*}{$\begin{array}{c}\text { SEM } \\
(\mathrm{n}=5)\end{array}$} & \multicolumn{3}{|c|}{$P$-value ${ }^{2}$} \\
\hline & LP & $\mathrm{HP}$ & & Trt & Time & Trt $\times$ Time \\
\hline Urinary pH & 8.09 & 8.07 & 0.021 & 0.41 & 0.24 & 0.57 \\
\hline Ruminal pH & 6.43 & 6.35 & 0.10 & 0.20 & 0.001 & 0.65 \\
\hline Ruminal fluid $\mathrm{P}_{\mathrm{i}}{ }^{3} \mathrm{mmol} / \mathrm{L}$ & 3.26 & 5.33 & 0.68 & 0.0001 & 0.006 & 0.34 \\
\hline Ammonia, $\mathrm{mmol} / \mathrm{L}$ & 7.04 & 7.35 & 0.68 & 0.73 & $<0.0001$ & 0.59 \\
\hline Total VFA, mmol/L & 105 & 105 & 6.21 & 0.96 & 0.05 & 0.72 \\
\hline Acetate, $\mathrm{mol} / 100 \mathrm{~mol}$ & 61.3 & 59.9 & 1.24 & 0.45 & 0.02 & 0.17 \\
\hline Propionate, mol/100 mol & 20.3 & 20.8 & 1.19 & 0.61 & 0.001 & 0.20 \\
\hline Isobutyrate, $\mathrm{mol} / 100 \mathrm{~mol}$ & 0.55 & 0.55 & 0.045 & 0.98 & 0.007 & 0.65 \\
\hline Butyrate, mol/100 mol & 14.2 & 14.6 & 0.91 & 0.61 & 0.12 & 0.46 \\
\hline Isovalerate, $\mathrm{mol} / 100 \mathrm{~mol}$ & 1.35 & 1.59 & 0.28 & 0.12 & 0.006 & 0.11 \\
\hline Valerate, $\mathrm{mol} / 100 \mathrm{~mol}$ & 1.45 & 1.57 & 0.065 & 0.23 & 0.0003 & 0.57 \\
\hline Caproate, $\mathrm{mol} / 100 \mathrm{~mol}$ & 0.87 & 0.99 & 0.082 & 0.30 & 0.002 & 0.69 \\
\hline
\end{tabular}

${ }^{1}$ Experimental diets had the same composition of ingredients with the exception that LP (low phosphorus) contained $0.5 \%$ of DM calcium carbonate and HP (high phosphorus) contained $0.5 \%$ of DM monosodium phosphate.

${ }^{2} P$-values for effects of treatment (Trt), sampling time (Time), and the interaction (Trt $\times$ Time).

${ }^{3} \mathrm{P}_{\mathrm{i}}=$ inorganic phosphate. 


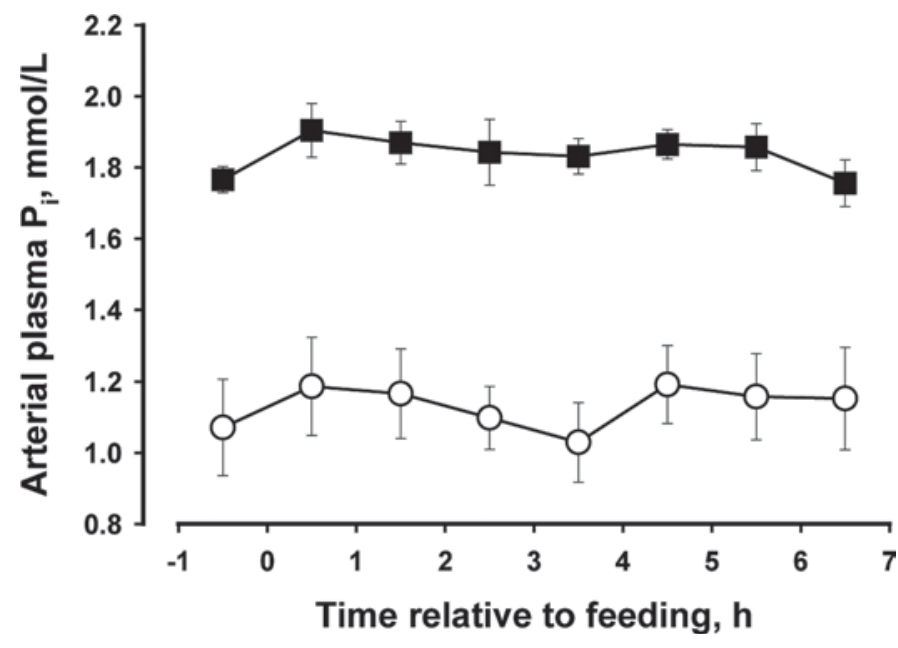

Figure 2. Arterial plasma inorganic phosphate $\left(\mathrm{P}_{\mathrm{i}}\right)$ concentration in cows fed either a low-phosphorus $(\mathrm{P})$ ration $(2.42 \mathrm{~g}$ of $\mathrm{P} / \mathrm{kg}$ of $\mathrm{DM}$; $\mathrm{O})$ or a high-P ration $(3.43 \mathrm{~g}$ of $\mathrm{P} / \mathrm{kg}$ of $\mathrm{DM} ; \mathbf{\square})$. Samples were collected $0.5 \mathrm{~h}$ before morning feeding as well as $0.5,1.5,2.5,3.5,4.5$, 5.5 , and $6.5 \mathrm{~h}$ after morning feeding. Each data point is the mean of 5 observations \pm standard error. The arterial plasma $P_{\mathrm{i}}$ concentration was affected by treatment $(P=0.001)$ and sampling time $(P=0.01)$, but no interaction was detected $(P=0.78)$.

decreased milk yield in a single lactation period when tP intake was decreased. Other studies with dairy cows have shown that prolonged feeding of P-depleted diets resulted in a decrease in milk production (Wu et al. 2000) along with decreases in DMI and BW (Valk and Sebek, 1999).

\section{Ruminal Environment}

Ruminal fermentation rate and protein synthesis might be decreased if the $\mathrm{P}_{\mathrm{i}}$ supply for microbial growth is not sufficient (Komisarczuk et al., 1987; Petri et al., 1988), and this may decrease digestibility of OM
(Kincaid and Rodehutscord, 2005) as well as DMI (Call et al., 1987; Valk and Sebek, 1999). Ruminal fluid and salivary $\mathrm{P}_{\mathrm{i}}$ concentrations are highly correlated and a decrease in tP intake has been shown to decrease plasma and ruminal $\mathrm{P}_{\mathrm{i}}$ concentration (Tomas et al. 1967). With adequate $\mathrm{P}$ supply, plasma concentrations of $\mathrm{P}_{\mathrm{i}}$ in ruminants are in the range of 1.5 and 2.5 $\mathrm{mmol} / \mathrm{L}$, and concentrations below $1.2 \mathrm{mmol} / \mathrm{L}$ may indicate $\mathrm{P}$ depletion (NRC, 2001). However, Wu et al. (2000) observed that plasma $\mathrm{P}_{\mathrm{i}}$ concentrations were not always good indicators of $\mathrm{P}$ status. In the present study, the mean plasma concentration of $\mathrm{P}_{\mathrm{i}}$ was 1.15 and $1.85 \mathrm{mmol} / \mathrm{L}$ with $\mathrm{LP}$ and HP, respectively. With $\mathrm{LP}$, cows were not depositing $\mathrm{P}$ in bone tissues and the present study, therefore, adds to the pool of evidence that a plasma $\mathrm{P}_{\mathrm{i}}$ concentration below $1.2 \mathrm{mmol} / \mathrm{L}$ is an indication of insufficient $\mathrm{P}$ supply. The ruminal $\mathrm{P}_{\mathrm{i}}$ concentration decreased from 5.33 to $3.26 \mathrm{mmol} / \mathrm{L}$ in LP. The required $\mathrm{P}_{\mathrm{i}}$ concentration for microbes was evaluated in vitro and reported to be between 0.7 and $2.6 \mathrm{mmol} / \mathrm{L}$ (Breves and Schröder, 1991). However, the requirements for ruminal $\mathrm{P}_{\mathrm{i}}$ concentrations in vivo have not been confirmed in lactating cows.

Digestibility of NDF decreased in response to decreased tP intake, whereas digestibility of $\mathrm{tP}$ was similar among treatments. Thus, a decreased NDF digestibility might indicate an alteration in microbial degradation of feedstuffs with decreased dietary tP supply. Petri et al. (1988) detected an increase in ruminal pH (6.86 vs. 6.11 ) and decreased ammonia concentrations; however, these effects accompanied decreases in DMI and might, therefore, be indirect effects of decreased tP intake. Cows in the present study were kept in tie stalls with wood shavings as bedding and although we did not observe any excessive intake of bedding with LP, we cannot rule out the possibility that the observed effect of treatment on NDF digestibility was affected by intake

Table 5. Arterial variables

\begin{tabular}{|c|c|c|c|c|c|c|}
\hline \multirow[b]{2}{*}{ Item } & \multicolumn{2}{|c|}{ Treatment $^{1}$} & \multirow{2}{*}{$\begin{array}{c}\text { SEM } \\
(\mathrm{n}=5)\end{array}$} & \multicolumn{3}{|c|}{$P$-value ${ }^{2}$} \\
\hline & LP & HP & & Trt & Time & Trt $\times$ Time \\
\hline \multicolumn{7}{|l|}{ Whole blood } \\
\hline Hematocrit, $\%$ & 25.7 & 26.0 & 0.014 & 0.07 & 0.44 & 0.07 \\
\hline Oxygen, mmol/L & 5.03 & 5.09 & 0.35 & 0.18 & 0.73 & 0.02 \\
\hline Carbon dioxide, $\mathrm{mmol} / \mathrm{L}$ & 24.9 & 24.1 & 0.66 & 0.18 & 0.07 & 0.87 \\
\hline \multicolumn{7}{|l|}{ Blood plasma, mmol/L } \\
\hline p-Aminohippuric acid & 0.072 & 0.086 & 0.007 & 0.15 & 0.31 & 0.91 \\
\hline Arterial plasma $\mathrm{P}_{\mathrm{i}}^{3}$ & 1.15 & 1.85 & 0.099 & 0.001 & 0.01 & 0.78 \\
\hline
\end{tabular}

${ }^{1}$ Experimental diets had the same composition of ingredients with the exception that LP (low phosphorus) contained $0.5 \%$ of DM calcium carbonate and HP (high phosphorus) contained $0.5 \%$ of DM monosodium phosphate.

${ }^{2} P$-values for the effects of treatment (Trt), sampling time (Time), and the interaction (Trt $\times$ Time).

${ }^{3} \mathrm{P}_{\mathrm{i}}=$ inorganic phosphate. 
Table 6. Blood plasma flows, net plasma fluxes, and recycling of inorganic phosphate $\left(\mathrm{P}_{\mathrm{i}}\right)$

\begin{tabular}{|c|c|c|c|c|c|c|}
\hline \multirow[b]{2}{*}{ Item } & \multicolumn{2}{|c|}{ Treatment $^{1}$} & \multirow{2}{*}{$\begin{array}{c}\text { SEM } \\
(\mathrm{n}=5)\end{array}$} & \multicolumn{3}{|c|}{$P$-value ${ }^{2}$} \\
\hline & LP & HP & & Trt & Time & Trt $\times$ Time \\
\hline \multicolumn{7}{|l|}{ Blood plasma flows, $\mathrm{L} / \mathrm{h}$} \\
\hline Portal vein & 1,149 & 1,172 & 104 & 0.60 & 0.10 & 0.28 \\
\hline Hepatic vein & 1,314 & 1,297 & 97.9 & 0.70 & 0.39 & 0.22 \\
\hline Hepatic artery & 167 & 126 & 72.0 & 0.46 & 0.78 & 0.38 \\
\hline \multicolumn{7}{|l|}{ Net plasma fluxes of $\mathrm{P}_{\mathrm{i}},{ }^{3} \mathrm{~g}$ of $\mathrm{P} / \mathrm{d}$} \\
\hline Portal & 57.1 & 65.5 & 4.75 & 0.20 & 0.21 & 0.33 \\
\hline Hepatic & 0.39 & 3.03 & 3.65 & 0.43 & 0.74 & 0.13 \\
\hline Splanchnic & 56.4 & 68.6 & 5.36 & 0.05 & 0.37 & 0.10 \\
\hline Net recycling of $\mathrm{P}_{\mathrm{i}},{ }^{4} \mathrm{~g}$ of $\mathrm{P} / \mathrm{d}$ & 29.7 & 28.6 & 4.21 & 0.86 & - & - \\
\hline \multicolumn{7}{|c|}{$\begin{array}{l}{ }^{1} \text { Experimental diets had the same composition of ingredients with the exception that LP (low } \\
\text { contained } 0.5 \% \text { of DM calcium carbonate and HP (high phosphorus) contained } 0.5 \% \text { of DM } \\
\text { phosphate. } \\
{ }^{2} P \text {-value for effects of treatment (Trt), sampling time (Time), and the interaction (Trt } \times \text { Time). } \\
{ }^{3} \mathrm{P}_{\mathrm{i}}=\text { inorganic phosphate. }\end{array}$} \\
\hline
\end{tabular}

of bedding. The observed effect on NDF digestibility might have been related to intake of bedding, and the lack of change in milk yield, ruminal $\mathrm{pH}$, VFA concentrations, and ammonia concentrations suggests that the decrease in NDF digestibility had little meaningful effect. If LP had been associated with decreased carbohydrate fermentation, we would have expected to find increased ammonia and decreased VFA concentrations with LP. The present study did not provide evidence for any changes in rumen function when ruminal $\mathrm{P}_{\mathrm{i}}$ concentrations were decreased to $3.3 \mathrm{mmol} / \mathrm{L}$ by decreasing tP intake.

\section{Salivary Secretion and Recycling of $P_{i}$}

Collection of saliva samples and especially quantification of mixed saliva secretion in conscious ruminants is difficult and subject to considerable errors, whether based on sponge technique (Valk et al., 2002), cardial collection (Cassida and Stokes, 1986), or permanent parotid duct fistulas (Tomas, 1973). It has been established that the salivary $\mathrm{P}_{\mathrm{i}}$ concentration is positively correlated to plasma $\mathrm{P}_{\mathrm{i}}$ concentrations (Challa and Braithwaite, 1988; Valk et al., 2002) and increasing dietary tP intake leads to increased plasma $\mathrm{P}_{\mathrm{i}}$ concentrations due to an increased absorption (Lueker and Lofgreen, 1961; Scott et al., 1985). However, the accumulation of $\mathrm{P}_{\mathrm{i}}$ in different salivary glands differs substantially (Breves and Schröder, 1991), which limits what can be inferred from measurements on saliva from single glands over short periods of time.

Contrasting theories on regulation of salivary $\mathrm{P}_{i}$ secretion exist. The "rumen support theory" suggests that salivary $\mathrm{P}_{\mathrm{i}}$ secretion is upregulated with low tP intakes to maintain high ruminal $\mathrm{P}_{\mathrm{i}}$ concentrations necessary for optimal microbial growth (Clark, 1953; Dias et al., 2009). The "homeostatic theory" suggests that the primary function of regulating salivary $\mathrm{P}_{\mathrm{i}}$ secretion is to maintain plasma $\mathrm{P}_{\mathrm{i}}$ homeostasis (Horst, 1986; Kebreab et al., 2005). Data from the present study support the view that salivary $P_{i}$ secretion is maintained at a disproportionately high concentration with low tP intakes in cattle in the short-term and, therefore, that salivary $\mathrm{P}_{\mathrm{i}}$ has a limited role in maintaining $\mathrm{P}_{\mathrm{i}}$ homeostasis at low intakes. However, this does not preclude that salivary $\mathrm{P}_{i}$ secretion is crucial in maintaining plasma $\mathrm{P}_{\mathrm{i}}$ homeostasis at high tP intakes.

Quantitative data on $\mathrm{P}_{\mathrm{i}}$ recycling in dairy cattle are sparse. Breves and Schröder (1991) estimated total $\mathrm{P}_{\mathrm{i}}$ recycling to be in the range of 30 to $60 \mathrm{~g}$ of $\mathrm{P} / \mathrm{d}$ and Kebreab et al. (2005) observed that duodenal P fluxes exceeded tP intake by 48 to $64 \mathrm{~g}$ of $\mathrm{P} / \mathrm{d}$ in cows fed at relatively high tP intakes compared with diets used in the present study. It has previously been observed that net portal $\mathrm{P}_{\mathrm{i}}$ fluxes exceeded tP intake (Reynolds et al., 1991). Recycling, estimated from net portal absorption of $\mathrm{P}_{\mathrm{i}}$, was 10 to $75 \mathrm{~g}$ of $\mathrm{P} / \mathrm{d}$ in cows at variable planes of nutrition (Kristensen et al., 2005). Available data point toward a total $\mathrm{P}_{\mathrm{i}}$ recycling in the same range as we have observed in the present study. However, available data from dairy cattle do not allow for evaluation of the recycling response to marginal undersupply of tP. In sheep, recycling of $\mathrm{P}_{\mathrm{i}}$ exceeded $\mathrm{tP}$ intake by a factor of 1.6 at high tP intake, whereas recycling exceeded intake by a factor of 3.9 at low intake (Scott et al., 1985). These data on sheep agree with the observation of the present study that $\mathrm{P}_{\mathrm{i}}$ recycling is not downregulated at low tP intakes. Thus, $\mathrm{P}_{\mathrm{i}}$ recycling cannot be the sole homeostatic mechanism in maintaining plasma $\mathrm{P}_{\mathrm{i}}$ concentrations. To the contrary, data in both sheep and dairy 
cattle indicate that salivary $\mathrm{P}_{\mathrm{i}}$ uptake is maintained at the expense of the plasma $\mathrm{P}_{\mathrm{i}}$ concentration. This might serve as an important adaptation to maintain ruminal $\mathrm{P}_{\mathrm{i}}$ supply during periods of dietary tP shortage.

\section{Phosphorus Homeostasis}

We suggest that the role of salivary $\mathrm{P}_{\mathrm{i}}$ secretion in $\mathrm{P}_{\mathrm{i}}$ homeostasis differs in situations with under- and oversupply of $\mathrm{P}$ in dairy cattle. In a situation with oversupply of $\mathrm{P}_{\mathrm{i}}$, upregulation of salivary secretion might be an important homeostatic response, ensuring a limited increase in plasma $\mathrm{P}_{\mathrm{i}}$. On the other hand, in situations with undersupply of $\mathrm{P}_{\mathrm{i}}$, the salivary secretion is maintained at a relatively high level, which forces other organs such as bones to increase $\mathrm{P}_{\mathrm{i}}$ supply. The constancy of milk tP secretion (Valk et al. 2002) suggests that the homeostatic adaptations to low tP intake must involve absorption or bone tissue balance of $\mathrm{P}_{\mathrm{i}}$.

Absorption. It is generally accepted that the main site of $\mathrm{P}_{\mathrm{i}}$ absorption is in the small intestine (Horst, 1986; Breves and Schröder, 1991). However, questions remain about the importance of endocrine control of absorption (Scott et al., 1985) and whether the intestinal absorption can respond to the increased demand for $\mathrm{P}_{\mathrm{i}}$ caused by relatively high salivary secretion at low tP intakes. Horst (1986) as well as Breves and Schröder (1991) suggested that, at least in monogastrics, the transport of $\mathrm{P}_{\mathrm{i}}$ by the small intestine involves an active $\mathrm{Na}^{+}$-coupled mechanism as well as a passive, nonsaturable $\mathrm{H}^{+}$-coupled transport. The active transport system appears to be readily saturable, which signifies that the passive transport may predominate in times of higher luminal $\mathrm{P}_{\mathrm{i}}$ concentrations (Breves and Schröder, 1991). In situations with low dietary tP intake, the active transport is upregulated by the vitamin $\mathrm{D}$ pathway, which results in an increase of $1,25-(\mathrm{OH})_{2} \mathrm{D}_{3}$ synthesis via kidneys stimulating intestinal $\mathrm{P}_{\mathrm{i}}$ absorption (Horst, 1986). However, the role of vitamin $D$ in ruminant $P_{i}$ absorption has been questioned by Field et al. (1983), who claimed that the absorptive mechanism is not subject to any regulation, and considered absorptive efficiency to be largely independent of dietary tP intake and that variation in fecal $\mathrm{tP}$ excretion is achieved through changes in salivary $\mathrm{P}_{\mathrm{i}}$ secretion alone.

Existing models on $\mathrm{P}_{\mathrm{i}}$ metabolism in dairy cows predict true $\mathrm{P}_{\mathrm{i}}$ absorption to be a hyperbolic function of intestinal $\mathrm{P}_{\mathrm{i}}$ concentration (Kebreab et al. 2004; Hill et al. 2008) reflecting that the dairy cow maintains a relatively constant apparent $\mathrm{P}_{\mathrm{i}}$ digestibility across a wide range of intestinal $P_{i}$ supplies. These previous observations, as well as the minute effects of treatment on apparent $\mathrm{P}_{\mathrm{i}}$ digestibility, as well as net portal $\mathrm{P}_{\mathrm{i}}$ flux relative to tP intake + recycled $\mathrm{P}_{\mathrm{i}}$ in the present study, indicate that regulation of intestinal $\mathrm{P}_{\mathrm{i}}$ absorption is not sufficient to maintain $\mathrm{P}_{\mathrm{i}}$ homeostasis in dairy cows challenged with decreased dietary tP intake.

Bone Metabolism and Phosphorus Balance. Phosphorus in the skeleton is mainly found in hydroxyapatite (Ternouth, 1990), and net bone resorption usually occurs in early lactation due to the rapid increase in milk production exceeding the rate of increase in DMI and the concomitant need for mobilization of $\mathrm{Ca}$ (Ramberg et al. 1970; Wu et al., 2000). Thus, skeletal reserves of $\mathrm{Ca}$ and $\mathrm{P}$ are normally decreased during early lactation and restored in late lactation and the dry period (Horst, 1986). Short-term negative tP balances cannot be regarded as detrimental if corrected later in lactation. In moderate P deficiency, such as occurred in the present study and others (Valk and Sebek, 1999; $\mathrm{Wu}$ et al. 2000), milk production is maintained due to the animal's ability to draw on its skeletal reserves (Karn, 2001).

Phosphorus balance, estimated by the use of total collection, does not allow for differentiation between $\mathrm{P}_{\mathrm{i}}$ resorption from bone and from soft tissue (Knowlton and Herbein, 2002). By using ${ }^{32} \mathrm{P}$ as a tracer, Braithwaite (1980) showed that $\mathrm{P}_{\mathrm{i}}$ mobilization primarily occurred from bone. It has been suggested by Blair-West et al. (1992) that not only rate of bone $\mathrm{P}_{\mathrm{i}}$ resorption, but also rate of bone $\mathrm{P}_{\mathrm{i}}$ accretion, is affected during dietary tP deficiency, as plasma concentration of osteocalcin, a marker of bone formation, was lowered in P-depleted beef cows compared with that in control animals. Together, data indicate that bone balance of tP plays a major role in $\mathrm{P}_{\mathrm{i}}$ homeostasis in dairy cows both in the postpartum transition period and during feeding of a P-deficient diet.

Urinary $\boldsymbol{P}$ Excretion. Urinary excretion of $\mathrm{P}_{\mathrm{i}}$ or tP in ruminants is usually insignificant due to efficient renal reabsorption of filtered $\mathrm{P}_{\mathrm{i}}$, but may be excessive in case of high dietary tP concentrations (Scott et al., 1985) or if saliva secretion is inhibited by feeding diets low in physical fiber (Scott and Buchan, 1988). Single animals have been reported to excrete significant amounts of $P_{i}$ via urine (Breves and Schröder, 1991). In the present experiment, the urinary tP excretion was negligible in both treatment groups (0.22 vs. $0.26 \mathrm{~g} / \mathrm{d})$, though slightly lowered with LP $(P=0.05)$. The small magnitude of the change supports the view that regulation of urinary $\mathrm{P}_{\mathrm{i}}$ excretion is without significance for the homeostatic adaptation to low tP intake in dairy cows.

\section{Meeting the Low P Intake Challenge}

Data from the present experiment point toward the need for considering situations with tP intake below 
and above recommendations separately, when reflecting on the most important regulatory mechanisms in maintaining $\mathrm{P}_{\mathrm{i}}$ homeostasis. In situations with high tP intake, the intestinal absorption can most probably not be decreased enough to limit $\mathrm{P}_{\mathrm{i}}$ absorption to the requirement. Bone accretion will account for a small fraction of the absorbed $\mathrm{P}_{\mathrm{i}}$ and salivary secretion will be the quantitatively most important excretion route. The exception would be situations with impaired salivation, where kidney reabsorption of $\mathrm{P}_{\mathrm{i}}$ decreases and urinary excretion functions as a second-level control. This is in contrast to monogastric animals where urinary excretion will dominate.

Because $P_{i}$ recycling did not decrease with decreased tP intake in the present study, despite a decreased plasma $\mathrm{P}_{\mathrm{i}}$ concentration, data are not in agreement with salivary $P_{i}$ secretion being of primary importance to $\mathrm{P}_{\mathrm{i}}$ homeostasis in the situation with low tP intake. Because intestinal absorption cannot be upregulated sufficiently to supply $\mathrm{P}_{\mathrm{i}}$ for recycling, bone resorption must balance the salivary $\mathrm{P}_{\mathrm{i}}$ flux maintained at a disproportionately high concentration. It is obvious that sufficient $\mathrm{P}_{\mathrm{i}}$ supply of rumen microbes is critical in ruminants (Muschen et al., 1988; Kincaid and Rodehutscord, 2005) and data indicate that $\mathrm{P}_{\mathrm{i}}$ supply to the rumen is highly prioritized in lactating dairy cows. Previous studies indicate that the cow will continue the investment in rumen function to the extent where it endangers chances to successfully initiate a new lactation (Valk and Sebek, 1999). It seems as if the cow invests in maximizing rumen fermentation in the short-term at the expense of the long-term consequences of depleting the bone pool.

The implications of the fact that dairy cows will prioritize ruminal $\mathrm{P}_{\mathrm{i}}$ supply over bone balance are that rumen function is partly protected from negative effects of low tP intakes, but also that this mechanism could be an important component of the inevitable endogenous loss of P in feces (Spiekers et al., 1993; Meschy, 2003). Therefore, it is difficult to fine tune $\mathrm{P}$ utilization of dairy cattle by manipulating dietary tP supply without a simultaneous attempt to manipulate salivary $\mathrm{P}_{\mathrm{i}}$ fluxes and more precisely define the ruminal need for $\mathrm{P}_{\mathrm{i}}$.

\section{CONCLUSIONS}

Net recycling of $\mathrm{P}_{\mathrm{i}}$ was not decreased in lactating dairy cows when tP intake was decreased despite a decrease in arterial plasma $P_{i}$ concentration. Recycling of $\mathrm{P}_{\mathrm{i}}$ was maintained at the expense of deposition of $\mathrm{P}_{\mathrm{i}}$ in bones and the tP balance decreased. Data are not consistent with salivary $\mathrm{P}_{\mathrm{i}}$ secretion being the primary regulator of $\mathrm{P}_{\mathrm{i}}$ homeostasis at low tP intakes. On the contrary maintaining salivary $\mathrm{P}_{\mathrm{i}}$ recycling at low tP intakes indicate that the cow prioritizes to maximize rumen function at the expense of long-term consequences of depletion of bone P. This might contribute to the relatively high inevitable $\mathrm{P}_{\mathrm{i}}$ loss in dairy cattle.

\section{ACKNOWLEDGMENTS}

We gratefully acknowledge Anne Krustrup and Birgit H. Løth, Faculty of Agricultural Sciences, Aarhus University (Tjele, Denmark), for skillful technical assistance. We thank Birgitte M. L. Raun and Betina A. Røjen for assistance with surgery and care of the cows. We also acknowledge the technical staff at the Faculty of Agricultural Sciences, Aarhus University for their skillful assistance. Funding was provided by The Directorate for Food, Fisheries and Agri Business, Copenhagen, Denmark (\#3304-VMP-05-024; \#3304VMP-05-005) and the Faculty of Agricultural Sciences, Aarhus University, Tjele, Denmark.

\section{REFERENCES}

Blair-West, J. R., D. A. Denton, M. J. McKinley, B. G. Radden, E. H. Ramshaw, and J. D. Wark. 1992. Behavioral and tissue responses to severe phosphorus depletion in cattle. Am. J. Physiol. Regul. Integr. Comp. Physiol. 263:R656-R663.

Braithwaite, G. D. 1980. The effect of dose-rate of 1-alpha-hydroxycholecalciferol on calcium and phosphorus-metabolism in sheep. Br. J. Nutr. 44:183-191.

Bravo, D., D. Sauvant, C. Bogaert, and F. Meschy. 2003. III. Quantitative aspects of phosphorus excretion in ruminants. Reprod. Nutr. Dev. 43:285-300.

Breves, G., and B. Schröder. 1991. Comparative aspects of gastrointestinal phosphorus metabolism. Nutr. Res. Rev. 4:125-140.

Call, J. W., J. E. Butcher, J. L. Shupe, R. C. Lamb, R. L. Boman, and A. E. Olson. 1987. Clinical effects of low dietary phosphorus concentrations in feed given to lactating dairy cows. Am. J. Vet. Res. 48:133-136.

Cassida, K. A., and M. R. Stokes. 1986. Eating and resting salivation in early lactation dairy cows. J. Dairy Sci. 69:1282-1292.

Challa, J., and G. D. Braithwaite. 1988. Phosphorus and calcium metabolism in growing calves with special emphasis on phosphorus homoeostasis. 3. Studies of the effect of continuous intravenous infusion of different levels of phosphorus in ruminating calves receiving adequate dietary phosphorus. J. Agric. Sci. 110:591-595.

Clark, R. 1953. A study of the water-soluble phosphate concentration of the ruminal contents in normal and phosphorus deficient animals. Onderstepoort J. Vet. Res. 26:137-140.

Dias, R. S., S. Lopez, T. Silva, R. M. P. Pardo, J. C. Silva Filho, D. M. S. S. Vitti, E. Kebreab, and J. France. 2009. Rumen phosphorus metabolism in sheep. J. Agric. Sci. 147:391-398.

Field, A. C., J. Kamphues, and J. A. Woolliams. 1983. The effect of dietary-intake of calcium and phosphorus on the absorption and excretion of phosphorus in chimaera-derived sheep. J. Agric. Sci. 101:597-602.

Hansen, B. 1989. Determination of nitrogen as elementary N, an alternative to Kjeldahl. Acta Agric. Scand. 39:113-118.

Harvey, R. B., and A. J. Brothers. 1962. Renal extraction of paraaminohippurate and creatinine measured by continuous in vivo sampling of arterial and renal-vein blood. Ann. N. Y. Acad. Sci. 102:46-54

Hill, S. R., K. F. Knowlton, E. Kebreab, J. France, and M. D. Hanigan. 2008. A model of phosphorus digestion and metabolism in the lactating dairy cow. J. Dairy Sci. 91:2021-2032. 
Horst, R. L. 1986. Regulation of calcium and phosphorus homeostasis in the dairy cow. J. Dairy Sci. 69:604-616.

Karn, J. F. 2001. Phosphorus nutrition of grazing cattle: A review. Anim. Feed Sci. Technol. 89:133-153.

Kebreab, E., J. A. N. Mills, L. A. Crompton, A. Bannink, J. Dijkstra, W. J. J. Gerrits, and J. France. 2004. An integrated mathematical model to evaluate nutrient partition in dairy cattle between the animal and its environment. Anim. Feed Sci. Technol. 112:131154.

Kebreab, E., M. A. Shah, D. E. Beever, D. J. Humphries, J. D. Sutton, J. France, and I. Mueller-Harvey. 2005. Effects of contrasting forage diets on phosphorus utilisation in lactating dairy cows. Livest. Prod. Sci. 93:125-135.

Kincaid, R. L., and M. Rodehutscord. 2005. Phosphorus metabolism in the rumen. Pages 187-194 in Nitrogen and Phosphorus Nutrition of Cattle. Reducing the Environmental Impact of Cattle Operations. E. Pfeffer and A. N. Hristov, ed. CABI Publishing, Wallingford, UK.

Knowlton, K. F., and J. H. Herbein. 2002. Phosphorus partitioning during early lactation in dairy cows fed diets varying in phosphorus content. J. Dairy Sci. 85:1227-1236.

Komisarczuk, S., R. J. Merry, and A. B. McAllan. 1987. Effect of different levels of phosphorus on rumen microbial fermentation and synthesis determined using a continuous culture technique. Br. J. Nutr. 57:279-290.

Kristensen, N. B., A. Danfaer, V. Tetens, and N. Agergaard. 1996. Portal recovery of intraruminally infused short-chain fatty acids in sheep. Acta Agric. Scand. Anim. Sci. 46:26-38.

Kristensen, N. B., B. A. Røjen, B. M. L. Raun, P. Lund, and J. Sehested. 2005. Quantification of net splanchnic inorganic phosphate recycling in lactating dairy cows. J. Dairy Sci. 88(Suppl. 1):60 (Abstr).

Kristensen, N. B., B. A. Røjen, B. M. L. Raun, A. C. Storm, L. Puggaard, and M. Larsen. 2009. Hepatic acetylation of the blood flow marker p-aminohippuric acid affect measurement of hepatic blood flow in cattle. Pages 558-559 in Ruminant Physiology. Digestion, Metabolism, and Effects of Nutrition on Reproduction and Welfare. Y. Chilliard, F. Glasser, Y. Faulconnier, F. Bocquier, I. Veissier, and M. Doreau, ed. Wageningen Academic Publishers, Wageningen, the Netherlands.

Kristensen, N. B., A. Storm, B. M. L. Raun, B. A. Røjen, and D. L. Harmon. 2007. Metabolism of silage alcohols in lactating dairy cows. J. Dairy Sci. 90:1364-1377.

Lueker, C. E., and G. P. Lofgreen. 1961. Effects of intake and calcium to phosphorus ratio on absorption of these elements by sheep. J. Nutr. 74:233-238.

Mertens, D. R. 2002. Gravimetric determination of amylase-treated neutral detergent fiber in feeds with refluxing in beakers or crucibles: Collaborative study. J. AOAC Int. 85:1217-1240.

Meschy, F. 2003. Re-assessment of dietary allowances: Absorbed phosphorus requirements in ruminants. Pages $175-190$ in Recent Advances in Animal Nutrition. P. C. Garnsworthy and J. Wiseman, ed. Nottingham University Press, Nottingham, UK.

Müschen, H., A. Petri, G. Breves, and E. Pfeffer. 1988. Response of lactating goats to low phosphorus intake. 1. Milk-yield and faecal excretion of P and Ca. J. Agric. Sci. 111:255-263.

NRC. 2001. Nutrient Requirements of Dairy Cattle. 7th rev. ed. National Research Council. National Academies Press, Washington, DC.

Petri, A., H. Müschen, G. Breves, O. Richter, and E. Pfeffer. 1988. Response of lactating goats to low phosphorus intake. 2. Nitrogen transfer from rumen ammonia to rumen microbes and proportion of milk protein derived from microbial amino-acids. J. Agric. Sci. 111:265-271.

Poulsen, H. D. 2009. Normtal for husdyrgødning - 2009. Accessed June 21, 2010. http://www.agrsci.dk/var/agrsci/storage/original/ application/6ad0435ef70c7cb3b7c30f15b406c0e3.

Ramberg, C. F., G. P. Mayer, D. S. Kronfeld, J. M. Phang, and M. Berman. 1970. Calcium kinetics in cows during late pregnancy, parturition, and early lactation. Am. J. Physiol. 219:1166-1177.

Reynolds, C. K., G. B. Huntington, H. F. Tyrrell, and P. J. Reynolds, 1991. Net absorption of macrominerals by portal-drained viscera of lactating Holstein cows and beef steers. J. Dairy Sci. 74:450459

Schurch, A. F., L. E. Lloyd, and E. W. Crampton. 1950. The use of chromic oxide as an index for determining the digestibility of a diet. J. Nutr. 41:629-636.

Scott, D., and W. Buchan. 1988. The effects of feeding pelleted diets made from either coarsely or finely ground hay on phosphorus balance and on the partition of phosphorus excretion between urine and faeces in the sheep. Q. J. Exp. Physiol. 73:315-322.

Scott, D., F. G. Whitelaw, W. Buchan, and L. A. Bruce. 1985. The effect of variation in phosphorus intake on salivary phosphorus secretion, net intestinal phosphorus absorption and fecal endogenous phosphorus excretion in sheep. J. Agric. Sci. 105:271-277.

Sehested, J. 2004. Feeding phosphorus (P) to cattle: A new basis for Nordic recommendations. Acta Agric. Scand. Anim. Sci. 4:169 180

Sjaunja, L. O., L. Baevre, L. Junkkarinen, J. Pedersen, and J. Setälä. 1991. A Nordic proposal for an energy corrected milk (ECM) formula. Pages 156-157 in Proc. 27th Session of International Committee for Recording Productivity of Milk Animals (ICRPMA) Eur. Assoc. Anim. Prod. Publ. No 50. Eur. Assoc. Anim. Prod., Wageningen, the Netherlands.

Spiekers, H., R. Brintrup, M. Balmelli, and E. Pfeffer. 1993. Influence of dry matter intake on faecal phosphorus losses in dairy cows fed rations low in phosphorus. J. Anim. Physiol. Anim. Nutr. (Berl.) 69:37-43.

Stoldt, W. 1952. Vorschlag zur vereinheitlichung der fett- bestimmung in lebensmitteln. Fette und Seifen 54:206-207.

Stuffins, C. B. 1967. The determination of phosphate and calcium in feeding stuffs. Analyst 92:107-111.

Ternouth, J. H. 1990. Phosphorus and beef production in northern Australia. 3. Phosphorus in cattle-A review. Trop. Grassl. $24: 159-169$

Tomas, F. M. 1973. Parotid salivary secretion in sheep-Its measurement and influence on phosphorus in rumen fluid. Q. J. Exp. Physiol. 58:131-138.

Tomas, F. M., R. J. Moir, and M. Somers. 1967. Phosphorus turnover in sheep. Aust. J. Agric. Res. 18:635-645.

Valk, H., and L. B. J. Sebek. 1999. Influence of long-term feeding of limited amounts of phosphorus on dry matter intake, milk production, and body weight of dairy cows. J. Dairy Sci. 82:2157-2163.

Valk, H., L. B. J. Sebek, and A. C. Beynen. 2002. Influence of phosphorus intake on excretion and blood plasma and saliva concentrations of phosphorus in dairy cows. J. Dairy Sci. 85:2642-2649.

Wu, Z., L. D. Satter, A. J. Blohowiak, R. H. Stauffacher, and J. H. Wilson. 2001. Milk production, estimated phosphorus excretion, and bone characteristics of dairy cows fed different amounts of phosphorus for two or three years. J. Dairy Sci. 84:1738-1748.

Wu, Z., L. D. Satter, and R. Sojo. 2000. Milk production, reproductive performance, and fecal excretion of phosphorus by dairy cows fed three amounts of phosphorus. J. Dairy Sci. 83:1028-1041. 